\title{
INTERNALISASI NILAI-NILAI SOFT-SKILL DALAM PEMBELAJARAN AKUNTANSI PADA SMK DI SURAKARTA
}

\author{
Budi Sutrisno \\ Dosen Prodi Pendidikan Akuntansi FKIP UMS \\ idubonsirtus@gmail.com
}

\begin{abstract}
This study aims at describing about (1) Soft-skills aspect characteristic was needed by Industrials and business, (2) The internalisation soft-skills values in Instructions and Assesment Models. This qualitative research with ethnography approach used at vocational schools setting in Surakarta, there are the State Owned $S M K$ as "N", the Islamic Private SMK as "I", and the Private SMK as "S",.Indebt interview and observation with documentations as a complement were involve the use of data collection. The information object is soft-skills kind that was need by ndustrials and business sector, and Internalisation Soft skills value in instructions and evaluations models at eknomic vocational schools of Surakarta. Data validity with data and resource triangulation. Data Analyses with interactive approach that sinergical of data collection, data reduction, data display, and conclution. The results are showed: 1) the soft-skills competence was needed by Industrials and business sector, had full the used by the third of SMK in Surakarta (2) The internalisation soft-skills value in Instructions and Evaluation Models is different. The State Owned SMK were use the Integrative instruction models, and the Private SMK so do them and complement model, (3) The Authentic Assesment model were used by the state owned but the private SMK were use the Conventional approach to step by step until Authentic evaluation.
\end{abstract}

Keywords: Internalidstion, Instructional, Authentic Assesment, Soft-Skills, SMK

\begin{abstract}
Absktrak: Penelitian ini bertujuan untuk menggambarkan karakteristik aspek softskills yang dibutuhkan oleh industri dan bisnis dan internalisasi nilai-nilai sof-skills dalam model intuksi dan assesmen. Penelitia etnografi ini menggambil setting di SMK Surakarta. Data dikumpulkan dengan interview mendalam dan observasi. Data dianalisis dengan menggunakan pendekatan interaktif. Hasil penelitian menunjukkan: 1. SMK di Surakarta telah secara utuh mengadopsi Jenis soft-skills yang diterapkan DU/Di, perbedaan aplkasinya terletak pada aspek intensitasnya, di mana SMK Negeri lebih intensif dibanding SMK Swasta. 2. Internalisasi nilai-nilai soft- skills dalam pembelajaran akuntansi yang diselenggarakan di kedua kelompok SMK tersebut cenderung tidak berbeda, SMK Negeri mengguakan pendekatan "Integratif", sedangkan SMK Swasta menggunakan pendekatan "Komplementatif dan integratif", dan 3) Model evaluasi yang diadopsi SMK Negeri menggunakan pendekatan Authentik, sedangkan SMK Swasta secara bertahap dan berjenjang mengadopsi pendekatan Konvensional untuk selanjutnya diterapkan pendelatan Authentik.
\end{abstract}

Kata kunci: internalisasi, instructional, authentic assesment, soft-skills, SMK 


\section{Pendahuluan}

Penyiapan SDM yang berkualifikas, senantiasa harus dikembangkan secara kontinyu guna menjawab tantangan jaman yang terus mengalami berubahan. Sutomo dan Budi Sutrisno ( 2013) menegaskan bahwa, kualifikasi dimaksud paling tidak harus mencakup 5 hal: "(1) mempunyai daya saing secara terbuka dengan bangsa lain; (2) adaptif dan antisipatif terhadap berbagai perubahan dan kondisi baru; (3) mampu belajar bagaimana belajar; (4) memiliki berbagai keterampilan yang mudah dilatih ulang; dan (5) memiliki dasar-dasar kemampuan luas, kuat, dan mendasar untuk berkembang".

Wagner (2008) dalam penelitiannya, menyarankan bahwa untuk menjawab tantangan global, diperllukan 7 ketrampilan yang harus dimiliki tiap SDM. Tujuh keterampilan baru dimaksud, yakni: (1) critical thinking and problem solving; (2) collaboration across networks and leading by influence; (3) agility and adaptability; (4) initiative and entrepreneurialism; (5) effective oral and written communication; (6 accessing and analyzing information; and (7) curiosity and imagination".

Menyikapi tuntutan globalisasi di atas, tentunya menjadi tanggung jawab dunia Pendidikan untuk itu, produk pendidikan dituntut memiliki delapan kompetensi pokok yakni: (1) communication skills; (2) critical and creative thinking; (3) inquiry/ reasoning skills; (4) nterpersonal skills; (5) multicultural/multilingual literacy; (6) problem solving; (7) information/digital literacy; dan (8) technological skills. Dari delapan kompetensi lulusan tersebut, dapat dipilah ke dalam 2 kelompok besar, yaitu: kompetensi $1 \mathrm{~s} / \mathrm{d} 6$ merupakan aspek softskills, sedang kompetensi 7 dan 8 adalah aspek hard skills.

Hasil survei ke industri manufaktur di daerah Yogyakarta yang dilakukan oleh Widarto, Pardjono, dan Noto Widodo (2013) menunjukkan bahwa aspek sikap/watak merupakan aspek yang memiliki kontribusi terbesar untuk menghasilkan produk yang berkualitas, selanjutnya secara berturutturut adalah kondisi fisik, pengetahuan dan keterampilan.

Melalui hasil survei tersebut, ditemukan fakta bahwa biasanya pihak perusahaan melakukan strategi sebagai berikut: Pertama, dalam memilih karyawan baru lebih menekankan pada aspek kompetensi sikap/ watak. Kedua, basic skills yang diutamakan bagi karyawan baru di bidang pembukuan adalah keahlian pokok akuntanasi, dan Administrasi Perkantoran. Ketiga, karyawan baru perlu pelatihan khusus yang dilakukan di dalam perusahaan, yang meliputi materi: Peraturan Perusahaan, K3, Motivasi, dan Wawasan ISO 9000.

Keadaan itu menarik mengingat selama ini pada dunia pendidikan, khususnya sekolah menengah kejuruan (SMK) yang notabine pencetak calon tenaga kerja industri, telah memilih untuk lebih menekankan kepada aspek keterampilan dan pengetahuan atau hard skills.

Di Indonesia, secara umum pengembangan aspek soft skills, belum dialokasikan dalam kurikulum pada porsi yang memadai. Fakta inilah yang merupakan suatu kesenjangan antara Dunia Pendidikan Kejuruan dan Dunia Industri.

Meyikapi kesenjangan dan kenyataan di atas, tentunya muncul pertanyaan sederhana di benak kita, lantas upaya internal manakah yang dilakukan fihak SMK guna memenuhi tuntutan jaman dan mendekatkan kesenjangan materi substansial antara kompetensi lulusan dengan kebutuhan dunia nyata.

Pemerintah tidak tinggal diam, melalui perubahan Kurikulum KTSP ke Kurikulum 2013 yang dikenal dengan " Kurtilas" merupakan upaya mendasar yang patut dihargai. Dalam pelaksanaannya, tidak semudah membalik telapak tangan. Berbagai upaya bertahap telah dilalui, mulai dari sosialisasi sampai dengan workshop dan pendampingan kepada para guru telah dilakukan secara serentak dalam skala nasional. 
"Kurtilas" yang pada hakikatnya menekankan teradopsinya kompetensi hardskills maupun soft-skills secara proporsional dan sesuai dengan dunia nyata. Hal ini tentunya menuntut strategi pembelajaran dan evaluasi yang selaras. Pendidikan persekolahan khususnya pada SMK yang di dalamnya terdiri dari berbagai SMK yang bersifat vaforit dan sarat dengan setumpuk bukti-bukti kualitas penyelengarannya sampai dengan SMK yang dalam tanda petik masih "gagap" dengan kondisi yang perlu perhatian, bantutan dan pembinaan secera berkesinambungan; dalam kenyataannnya sama-sama menghasilkan lulusan yang akan menghadapi dunia nyata dan mereka harus menselaraskan diri guna memenangkan persaingan yang makin ketat. Adanya kenyataan terjadinya disparitas kualitas kompetensi lulusan inilah, yang hingga saat ini masih sangat perlu mendapat perhatian yang lebih serius dari berbagai fihak.

Berdasarkan deskripsi di atas, maka dianggap sangat mendesak untuk dilakukan perubahan manajemen SMK dalam penyelarasan diri dengan tuntutan kompetensi lulusan yang dibutuhkan DU/DI, dalam bentuk rencana strategis yang dituangkan dalam serangkaian konsep pengembangan diri berupa "internalisasi nilai-nilai softskills ke dalam Hard-skills disertai upaya nyata dalam pelaksanaan pembelajaran dan evaluasinya".

Tujuan penulisan artikel hasil penelitian di SMK Surakarta tahun 2016 ini mendeskripsikan model-model internalisasi nilai-nilai soft-skillsi dalam pembelajaran akuntansi dan proses evaluasinya, yang secara terinci dideskripsikan aspek-aspek: a) Jenis soft-skill yang dibutuhkan DU/DI, b) Model-model Internalisasi nilai-nilai softskills dalam pembelajaran akuntansi, dan c) Kebijakan Model evaluasi pembelajaran soft skill di bidang akuntansi yang dilakukan oleh sekolah dalam menjawab tuntutan DU/DI.

Amirulloh (2015: 10) menjelaskan definisi internalisasi sebagai upaya memasukan pengetahuan (knowing) dan ketrampingetln melaksanakan pengetahuan itu menjadi kepribadiannya (being) dalam kehidupan sehari-hari. Pengetahuan dimaksud merupakan suatu konsep netrakl maupun konsep yang mengandung nilai yang sudah diketahui. Pengetahuan dan ketrampilan untuk melaksanakannya, tentunya masih bersifat eksternal, sehingga upaya memasukan ke dalam pribadi membutuhkan serangkain strategi yang hiterogen sesuai dengan bobot pengetahuan dan kesiapan individu dalam menerimanya untuk kemudian terampil dalam melaksanakannya.

Secara sistemik, konsep dasar Pendidikan Kejuruan pada dasarnya merupakan subsistem dari sistem pendidikan. Menurut Muchlas Samani, (2005:14) "Terdapat banyak definisi yang diajukan oleh para ahli tentang pendidikan kejuruan dan definisi-definisi tersebut berkembang seirama dengan persepsi dan harapan masyarakat tentang peran yang harus dijalankannya”.

Bagi masyarakat Indonesia misi pendidikan kejuruan adalah sangat penting karena pada umumnya siswa sekolah kejuruan berasal dari masyarakat dengan tingkat sosial ekonomi rendah (Suprapto Brotosiswoyo, 1991:8); Konsekuensi dari gejala umum ini dapat diartikan bahwa apabila sekolah kejuruan berhasil mewujudkan misinya berarti akan membantu menaikan status sosial ekonomi masyarakat tingkat bawah. Dengan kata lain, Elliot menegaskan bahwa sekolah kejuruan dapat membantu meningkatkan mobilitas vertikal dalam masyarakat (Elliot, 2003:42).

Tentu saja sekolah kejuruan tidak terlepas dar fungsinya sebagaimana dikatakan oleh Baedhowi (2008:1),

"fungsi penyelenggaraan pendidikan kejuruan adalah: (1) menyiapkan peserta didik yang mampu meningkatkan kualitas hidup; (2) mampu mengembangkan diri, dan memiliki keahlian dan keberanian membuka peluang meningkatkan penghasilan; (3) menyiapkan siswa menjadi tenaga kerja produktif; (4) memenuhi keperluan tenaga kerja dunia usaha dan dunia industri; (5) 
menciptakan lapangan kerja bagi dirinya dan bagi orang lain; (6) mengubah statussiswa dan ketergantungan menjadi bangsa yang berpenghasilan (produktif), dan (7) menyiapkan siswa menguasai IPTEK".

Dengan demilian mereka mengikuti, menguasai dan menyesuaikan din dengan kemajuan IPTEK serta memiliki kemampuan dasar untuk dapat mengembangkan din secara berkelanjutan.

Kemampuan Akuntansi adalah kemampuan pada aspek ketrampilan intelektual dalam bentuk kemampuan elaborasi pemecahan masalah yang terdiri dari kemampuan menggunakan prosedur (use) dan kemampuan menemukan (find) pemecahan masalah Akuntansi dengan jenis unjuk kerja berupa urutan tindakan yang kriterianya dapat berbentuk bagian dari skema atau dapat dalam bentuk pengembangan skema baruKompetensi Akuntansi terdiri dari kecakapan-kecakapan yang dibentuk melalui pengetahuan, ketrampilan dan pembinaan sikap tentang Akuntansi. Akuntansi sendiri adalah seni catat-mencatat transaksi keuangan yang bertujuan menyajikan informasi bagi pihak-pihak yang berkepentingan sesuai dengan kapasitas tujuan penggunaannya.

Hermanson, Edwards \& Salmonson (1989:3) mendefinisikan Akuntansi sebagai "... the process of identifying, measuring, and communicating economic information to permit informed judgments and decisions by the users of the information." Akuntansi adalah proses pencatatan, pengklasifikasian, pengikhtisaran, pelaporan dan penginterpretasian transaksi-transaksi yang terjadi dalam suatu perusahaan untuk memungkinkan adanya asesmen dan keputusan yang jelas dan tegas bagi mereka yang menggunakan informasi tersebut. (P2A, Depdikbud, 1989:15).

Menurut National Committee on Governmental Accounting, 1968 (Gandhi, 2002:86) Akuntansi adalah gabungan dari aktivitas analisis, pencatatan, peringkasan dan penginterprestasian transaksi keuangan; bertujuan untuk menyediakan informasi keuangan yang lengkap dan akurat dalam bentuk yang sesuai dan dalam waktu yang tepat.

Dari beberapa definisi dan penegasan tersebut dapat disimpulkan bahwa kompetensi Akuntansi mengandung penguasaan kemampuan dan aktivitas yang berproses mengikuti prosedur tertentu dalam tahapantahapan mulai dari mencatat, mengklasifikasi, mengikhtisarkan, melaporkan dan menginterpretasikan transaksi yang terjadi dalam suatu perusahaan dalam kurun waktu tertentu dengan tujuan menyediakan informasi keuangan kepada pihak yang berkepentingan untuk tujuan pengambilan keputusan dan sebagai sarana evaluasi kegiatan bisnis.

Menurut Moyo \& Hagman ( 2000:4) lulusan harus diberikan kapasitas kompetensi yang interdisiplin yaitu hard-skills dan soft-skills. Tetapi sayangnya selama ini pendidikan soft-skill tidak secara eksplisit dicantumkan dalam kurikulum yang ada di sekolah, sehingga seringkali banyak guru dan bahkan sekolah tidak secara langsung dapat merencanakan dan mengajarkan pendidikan soft- skill'".

Bernd Schulz, 2008:147), menegaskan bahwa:

"Soft-skill sendiri diartikan sebagai seluruh aspe dari generic skill yang juga termasuk elemen-elemen kognitif yang berhubungan dengan nonacademic skill (Sharma,2009:11). Softskill menyangkut kategori personal qualities, interpersonal skill, and additional skill/knowledge, yang mana semua hal tersebut akan memberikan kontribusi pada kemampuan kompetensi secara keseluruahan"

Kualitas personal adalah kualitas seseorang yang menyangkut kompetensi diri seperti kreativitas, kemampuan berpikir dan memecahkan, memimpin, kemampuan negosiasi, kemampuan presentasi, 
kemampuan komunikasi, kemampuan menjalin relasi, dan kemampuan bicara dimuka umum.

Secara eksplisit telah terlihat bahwa soft-skill sangat diperlukan dalam pemanfaatannya pada aspek perencanaan dan proses pencarian pekerjaan serta kesuksesan meniti karir pekerjaan. Hal ini mengindikasikan bahwa soft-skill menentukan kecepatan lulusan mendapatkan pekerjaan, selain didukung oleh hard-skillnya.

Ruben andDeAngelis (2008), menyatakan bahwa: "Hasil surveynya mengelompokkan kompetensi yang dibutuhkan dan seseorang dapat sukses meniti karir dan kehidupannya, yaitu kompetensi personal, komunikasi, organisasi, internasional/ antar budaya dan domain". Sedangkan Puliam (2008:211) "menyebutkan bahwa skill yang paling dicari oleh pemberi kerja adalah keterampilan komunikasi, integritas/ kejujuran, keterampilan interpersonal, motivasi/inisiatif, etika kerja yang kuat, bekerja dalam tim, keterampilan komputer, analitis, fleksibilitas/ adaptibilitas, dan detail oriented".

Pengembangan kualitas sumber daya manusia harus berorentasi pada segi kemampuan tehnis, teoritis, konseptual, Mangkuprawiro (2002:135). Untuk itu Kurikulum Sekolah Menengah Kejuruan harus dikemas dengan pendekatan Kurikulum berbais pengembangan kecakapan hidup (life-skill). Dengan pendekatan berbagai kurikulum pendidikan SMK sebagai sistem pendidikan yang menyiapkan lulusannya untuk siap kerja harus mampu menghasilkan lulusan yang dapat bersaing dalam dunia global dan sebagai antisipasi adanya perubahan kebutuhan di dunia kerja yang terwujud dalam perubahan persyaratan dalam menerima tenaga kerja, yaitu adanya persyaratan soft-skill yang dominan disamping hard-skill-nya. Secara jelas ditunjukkan bahwa soft-skill sangat dibutuhkan lulusan untuk dapat bersaing dalam mendapatkan pekerjaan, meniti karir dalam pekerjaannya dan ataun untuk berwirausaha.

Walaupun demikian, aplikasi pengelolaan kompetensi soft-skills oleh sekolah, ditegaskan oleh Sutrisno(2016) bahwa:

"Tidak selamanya mampu menjamin optimalisasi hasil kecuali mempertimbangkan tiga aspek berikut: (1) menyadari diri sendiri terhadap peluang-peluang, kesempatankesempatan, kendala-kendala, pilihanpilihan, dan konsekuensi-konsekuensi; (2) mengidentifikasi tujuan-tujuan yang berkaitan dengan tujuan; (3) penyusunan program kerja pendidikan, yang berhubungan dengan pengalamanpengalaman yang bersifat pengembangan guna menyediakan arah, waktu, dan urutan langkah-langkah yang diambil untuk meraih tujuan karir".

Proses pembelajaran di sekolah atau perguruan tinggi sedang mengalami pergeseran dari berbasis isi ke berbasis kompetensi, dan saat ini berbasis kebutuhan masyarakat sehingga harus berkontribusi bagi pengembangan pengetahuan, sikap dan ketrampilan secara utuh dan terintegrasi. Konotasi pembaruan proses pembelajaran ini apabila dijalankan, maka tidak terlalu sulit untuk para alumnus merubah dirinya dari yang kurang kompeten menjadi yang paling kompeten. Perubahan yang dimaksud dalam Permendikbud no:103 dan 104 tahun 2014, bukan semata-mata hanya mengganti daftar mata kuliah, atau susunan mata kuliah, melainkan yang lebih hakiki adalah perubahan proses pembelajaran, penyampaian dan evaluasinya. Proses pembelajaran dari teachercentered ke sutdent centered learning, dan dari proses evaluasi sesaat yang hanya membidik aspek Kognitif, ke model evaluasi Authentic yang bersifat integratif dengan mengintegrasikan antara aspek Kognitif, afektif, dan psikomotorik secara selaras dan berimbang 
Proses pembelajaran yang menggunakan pendekatan SCL (Student Centered Learning) menjadi salah satu pilihan dalam Kurikulum 2013 ini. Soft-skills dikembangkan tidak seharusnya melalui satu mata pelajaran, melainkan di integrasikan di setiap mata pelajaran. Apabila atribut soft-skills yang akan dikembangkan adalah komunikasi lisan, maka proses pembelajaran yang menggunakan presentasi, diskusi, diskusi kelompok menjadi perlu dilakukan. Namun, apabila aspek kolaboratif yang akan difokuskan, maka penugasan berkelompok perlu dilakukan.

Soft-skill merupakan kemampuan khusus, yang mencakup aspek social interaction, ketrampilan teknis dan managerial. Kemampuan ini harus dimiliki tiap siswa dalam memasuki dunia kerja. Seperti diungkapkan oleh Hakim Nasution (2006) dalam seminar soft-skill, "Kunci Menuju Sukses" yang disenggarakan di ITS, memberikan gambaran terjadinya kondisi terbalik di dunia pendidikan, di mana kompetensi hard skill yang disediakan mencapai $90 \%$ dan soft-skill hanya $10 \%$, tetapi fakta dilapangan ( DU/DI ) justru mebutuhkan soft-skill 20\%. Dari fakta tersebut, lanjutnya, dapat ditarik benang merah bahwa dalam memasuki dunia kerja soft skill-lah yang mempunyai peran yang lebih dominan.

Pembelajaran soft-skills menurut Hermanto, dapat dilakukan melalui tiga model, yaitu: 1). Model terpisah sebagai pembelajaran soft- skills atau diskrit, pelaksanaannya dikemas secara khusus, tidak tercantum di dalam kurikulum. Ini diterapkan melalui program kepemimpinan, 2). Model terintegrasi yaitu menyatu dengan hard-skills artinya melekat dan terpadu dengan program kurikuler, kurikulum yang ada atau dalam pembelajaran yang ada atau dalam proses pembelajaran. 3). Model komplementatif, artinya implementasi soft-skills ditambahkan ke dalam program pendidikan kurikuler dan struktur kurikulum yang ada (Herminarto, 2008: 6-7).
Model yang mampu menyatukan soft skills secara seimbang baik pada saat guru merancang pembelajaran, mengimplementasikan dan mengevaluasi, disebut model pembelajaran soft skills terintegrasi. Model pembelajaran ini dapat dilakukan guru dengan mudah karena softskills terintegrasi pada topik-topik hardskils yang menjadi inti kompetensi mata pelajaran.

Model ini diawali dengan kajian softskills hasil analsis kebutuhan kompetensi soft skills dari industri dan kebutuhan kurikulum. Selanjutnya temuan soft- skills tersebut diintegrasikan kedalam topiktopik hard-skills yang menjadi content. Integrasi soft- skills ini juga terdiskripsikan kedalam tujuan pembelajaran dan pada diri siswa serta pengalaman pembelajaran. Tujuan pembelajaran menjadi dasar bagi siswa dan guru dalam memahami capaian belajar sekaligus sebagai penuntut adanya standar kerja soft-skills dan hard-skills atau multi target (nested). Integrasi pada diri siswa menjelaskan proses internalisasi yang terjadi sejalan dengan waktu dan mekanisme pembelajaran yang dikreasikan guru. Pengalaman belajar merupakan implementasi dari proses pembudayaan yang menekankan pada manajemen performen.

Model pembelajaran skills dapat dikembangkan dengan bertumpu pada pembelajaran kognitivism, construktivism, behaviourism, dan humanism yang digunakan secara eklektik. Karena itu selama pembelajaran dikembangkan konsep soft skills, berupa kemampuan berfikir kritis, belajar melalui fakta-fakta yang ditemui pada saat praktek, mencoba menganalisis dan membuat pernyataan-pertanyaan untuk meneguhkan perilaku soft-skills. Hal ini dilakukan melalui diskusi, refleksi diri ataupun menganalisis balikan, harapannya penguasaan konsep soft-skills oleh siswa semakin kokoh. Situasi pembelajaran yang diciptakan guru harus mampu menumbuhkan, menjaga maupun menguatkan soft skills. Pola penguatan dapat dikembangkan guru 
sebagai bentuk dari konsekuensi perilaku yang ditampilkan selama pembelajaran.

Pembelajaran hard-skills pada umumnya menekankan pada aspek kognitif dan psikomotorik, sedangkan pembelajaran soft-skills lebih menekankan penguasaan aspek afektif, dan bersifat pribadi, meliputi komponen personal dan interpersonal. Karena kedua pola pembelajaran soft-skills tersebut diselenggarakan dalam situasi yang berkelanjutan (continues process), maka evaluasi dilakukan dalam tiga tahap yaitu sebelum, selama dan sesudah pembelajaran atau measure ongoing performance. Model evaluasi ini dimaksudkan untuk memperoleh berbagai informasi secara berkelanjutan tentang perkembangan siswa dari sisi kognitif dan skill. Selain itu untuk meyakinkan bahwa penguasaan kompetensi skills telah mencapai tingkat mastery, menunjukkan performa kerja yang terstandar. Melalui mekanisme evaluasi dengan pendekatan perbaikan berkelanjutan ini, performa kerja hard dan soft-skills siswa akan tercapai secara maksimal dan selaras dengan kebutuhan stakeholder.

Pengukuran hard-skills tentunya lebih mengarah pada aspek cognitive dan ketrampilan motorik siswa, sehingga cenderung menggunakan alat ukur tes berupa poryek maupun unjuk kerja; sedangkan soft-skills yang menekankan aspek afektif, menggunakan alat ukur non tes, berupa studi persepsi, pendapat dan kategori. Instrumen yang digunakan dapat dipilih dengan pertimbangan saling melengkapi seperti observasi, angket, portofolio, ekspresi diri, dan self evaluation. Format evaluasi dibuat agar dapat dipergunakan oleh guru, teman, dan diri sendiri. Pengembangan instrumen ditentukan oleh dimensi masing-masing berdasarkan kedalaman dan keluasan. Kajian tentang masing-masing dimensi, ditentukan oleh materi ajar yang menggambarkan aspek hard-skills secara terpisah dan aspek soft-skills yang cenderung terintegrasi. Hasil evaluasi akan memberi gambaran perkembangan perubahan penguasaan skills dibandingkan dengan standar.

\section{Metode Penelitian}

Penelitian ini merupakan jenis penelitian kualitatif. Penelitian kualitatif, menurut Moleong, (2002: 7), " memanfaatkan analisis data secara induktif. Selain itu, ciri lainnya adalah manusia adalah sebagai alat penelitian, sasaran penelitian mengarah pada usaha menemukan teori dasar, bersifat deskriptif, lebih mementingkan proses daripada hasil, dan ada batasan studi dilakukan dalam rangka keabsahan data, rancangan penelitian (yang bersifat sementara), hasil penelitian dan subyek penelitian". hal yang sama juga ditegaskan oleh Sugiyono, (2006:18). Usman \& Akbar (2001 : 81) mengemukakan bahwa, "metode kualitatif berarti metode penelitian yang dilakukan dalam situasi yang wajar (natural setting) dan data yang dikumpulkan umumnya bersifat kualitatif”.

Pemilihan pendekatan kualitatif berdasarkan pada pertimbangan bahwa gejala dalam penelitian ini merupakan proses pembelajaran dan evaluasinya pada mata pelajaran produktif, yang perlu dilakukan melalui kajian terhadap aktifitas guru dan siswa. Pada pendekatan ini, kehadiran peneliti dilaksanakan secara wajar sebagaimana adanya.

Pemilihan informan disini meliputi kepala SMK dan guru bidang akuntansi di Surakarta untuk mata pelajaran produktif terkait. Melalui key-informen, penelitian ini berusaha untuk mengungkapkan informasi sebanyak mungkin mengenai pelaksanaan internalisasi nilai-nilai soft-skills dalam pembelajaran akuntansi di SMK, serta upayaupaya yang dilakukan oleh sekolah dalam rangka meningkatkan output pembelajarnnya. Di samping itu penelitian juga dilakukan di lingkungan DU/DI di Surakarta dalam memperoleh informasi tentang analisis kebutuhan kompetensi karyawan beserta karakteristik kompetensi soft-skill yang diutamakan nya.

Setting penelitian dalam penelitian ini merupakan wadah pencarian data secara fisik yang terdiri dari tiga dimensi yaitu tempat, pelaku dan aktivitas. Pertama, dimensi 
tempat yaitu SMK Negeri "N" Surakarta ( perwakilan sekolah negeri ), dan SMK "I" ( perwakilan SMK Swasta berbasis Islam ), dan SMK "S" ( perwakilan sekolah swasta murni ). Kedua, dimensi pelaku yaitu guru, siswa, dan kepala sekolah, serta pimpinan DU/ DI. Ketiga, Peneliti melakukan pengamatan tingkah laku subyek, yang pada gilirannya akan memperoleh informasi penting dari suatu kegiatan yang menjadi obyek penelitian.

Teknik pengumpulan data yang digunakan dalam penelitian ini meliputi: 1) Observasi / Pengamatan. Observasi dilakukan dengan cara mengamati secara langsung tentang pelaksanaan internalisasi nilai-nilai soft-skill dalam pembelajaran akuntansi beserta evaluasinya yang dilakukan oleh guru SMK bidang ekonomi di Surakarta. Pengamatan mengoptimalkan kemampuan peneliti dari segi motif, kepercayaan, perhatian, perilaku tak sadar, dan kebiasaan sehingga memungkinkan pengamat untuk melihat fakta pembelajaran tesebut sebagaimana adanya. 2) Wawancara. Wawancara dilakukan secara mendalam baik secara formal maupun informal. Wawancara informal mengandung unsur spontanitas, santai, tanpa pola atau arah yang ditentukan sebelumnya. Sedangkan wawancara formal menggunakan garis-garis pokok, topik atau masalah yang dijadikan pegangan dalam pembicaraan. Wawancara dilakukan secara terstruktur dengan menentukan masalah dan pertanyaan-pertanyaan untuk mencari data yang diperlukan. Wawancara dilakukan untuk mengetahui informasi yang mendukung tercapainya tujuan penelitian (Moleong, 2002 : 135-146). 3) Dokumentasi. Dokumen berguna untuk memberikan latar belakang yang lebih luas mengenai pokok penelitian, dapat dijadikan bahan untuk mengecek kesesuaian data dan bahan utama dalam penelitian ( Moleong, 2002:160163). Teknik ini digunakan untuk mengali data deskripsi DU/DI dan sekolah, yang menyangkut tuntutan kompetensi dalam rekrutmen karyawan, penerapan kurikulum, pembelajaran dan evaluasinya dan aspek jumlah maupun kualitas lulusan, out-come, serta system kerjasama dalam pelaksanaan Prakerin.

Validitas data merupakan faktor penting bagi penelitian, oleh karena itu pemeriksaan atas data sebelum dilakukan analisis adalah mutlak adanya. Untuk menguji validitas data dalam penelitian ini digunakan teknik triangulasi. Denzin ( Moleong, 2002 : 15) membedakan empat macam triangulasi sebagai teknik pengujian data yaitu dengan menggunakan sumber, metode, penyelidik dan teori. Dari empat macam triangulasi ini yang digunakan adalah pengujian berbasis sumber, karena fokus kajian terletak pada tindakan subyek, maka harus didukung oleh akurasi data dari sumber yang relevan dan representatif.

Data yang berhasil dikumpulkan, dianalisis dengan menggunakan model analisis interkatif (Sutopo, 2002: 87). Dalam model analisis ini, tiga komponen analisisnya, yaitu reduksi data, sajian data dan penarikan kesimpulan/verifikasi dilaksanakan bersama dengan proses pengumpulan data dalam bentuk interaktif melalui proses siklus.

Teknik analisis data dilakukan dengan langkah-langlah: (1) reduksi data, yaitu proses pemilihan, pemusatan perhatian pada penyederhanaan atau menyingkat data dalam bentuk uraian secara rinci dan sistematis, yakni menonjolkan hal-hal pokok yang penting seperti proses internalisasi nilai-nilai soft-skills dalam pembelajaran akuntansi dan evaluasinya gar lebih mudah dikendalikan, (2) display data, yaitu upaya menyajikan data dengan melihat gambaran proses pembelajaran secara keseluruhan atau bagian tertentu dari penelitian, (3) kesimpulkan dan verifikasi, yaitu upaya untuk mencari makna terhadap data yang dikumpulkan dengan mencari pola, hubungan, persamaan yang sering timbul, yang berupa kesesuaian karakter soft-skills dengan kompetensi yang ditonjolkan dalam pembelajaran akuntansi dan model evaluasinya. 


\section{Hasil dan Pembahasan}

\section{A. Karakteristik aspek soft-skill yang dibutuhkan DU/DI}

Jenis Soft Skills yang dibutuhkan Du/Di dan dikembangkan oleh SMK di Surakarta dapat dipaparkan dalam tabel 1. Berikut ini.

Tabel 1. Jenis Soft Skills yang dikembangkan

\begin{tabular}{|c|c|c|c|c|c|}
\hline No & Jenis Soft Skill & Du/Di & SMK “N" & SMK "I" & SMK "S" \\
\hline 1 & Bekerja cekatan, rapi, bersih, aman, jujur. & $\sqrt{ }$ & $\sqrt{ }$ & $\sqrt{ }$ & $\sqrt{ }$ \\
\hline 2 & Rasa bangga terhadap pekerjaan. & $\sqrt{ }$ & $\sqrt{ }$ & $\sqrt{ }$ & $\sqrt{ }$ \\
\hline 3 & $\begin{array}{l}\text { Kerja keras, dalam wujud mengutamakan mutu, } \\
\text { dan kualitas. }\end{array}$ & $\sqrt{ }$ & $\sqrt{ }$ & $\sqrt{ }$ & $\sqrt{ }$ \\
\hline 4 & Bekerja sama dalam tim. & $\sqrt{ }$ & $\sqrt{ }$ & $\sqrt{ }$ & $\sqrt{ }$ \\
\hline 5 & Menghargai karya orang lain. & $\sqrt{ }$ & $\sqrt{ }$ & $\sqrt{ }$ & $\sqrt{ }$ \\
\hline 6 & Belajar sepanjang waktu. & $\sqrt{ }$ & $\sqrt{ }$ & $\sqrt{ }$ & $\sqrt{ }$ \\
\hline \multirow[t]{2}{*}{7} & $\begin{array}{l}\text { Bekerja efektif, efisien dan produktif sebagai } \\
\text { cerminan dari strategi berfikir. Kreatif dan }\end{array}$ & $\sqrt{ }$ & $\sqrt{ }$ & $\sqrt{ }$ & $\sqrt{ }$ \\
\hline & inovatif. & $\sqrt{ }$ & $\sqrt{ }$ & $\sqrt{ }$ & $\sqrt{ }$ \\
\hline 8 & Kekuatan untuk berubah. & $\sqrt{ }$ & $\sqrt{ }$ & $\sqrt{ }$ & $\sqrt{ }$ \\
\hline 9 & Komunikasi verbal dan non-verbal. & $\sqrt{ }$ & $\mathrm{v}$ & -- & -- \\
\hline
\end{tabular}

Sajian data di atas menunjukan bahwa semua soft-skills yang dikembangkan dalam dunia kerja dan dunia industri dan sekaligus menjadi dasar rekrutmennya, ternyata telah diadopsi oleh tiga (3) SMK objek penelitian ini, kecuali kompetensi ke 10 yang tidak diadopsi oleh SMK Swasta, dengan pertimbangan hanya dilaksanakan dalam pembelajaran bahasa Indonesia dan Bahasa Inggris. Yang lebih menarik adalah ketiga sekolah itu tidak memiliki sarana laboratorium bahasa.

Perbedaan pelaksanaan dari kompetensi yang dikembangkan oleh SMK dalam upaya pencapaiannya memiliki intensitas yang berbeda. Hal ini lebih didasarkan pada faktor kelengkapan instrument sekolah yang berupa Kompetensi guru, Laboratorium dan peralatan terkait, sarana dan prasarana , Keuangan, keluasan jaringan, serta model pembelajaran yang dikembangkan. Pada SMK Negeri, yang tentunya memliki faktorfaktor pendukung terkait yang lebih memadai dibanding SMK Swasta yang diteliti.

Jika disimak lebih lanjut, hasil kajian ini mendukung pernyataan Harris (1977:20), bahwa dalam kenyataannya belum semua soft skills yang dianggap penting telah diadopsi dan terkuasai dengan baik. Demikian pula dengan Finc \& Crunkilton (1989:248), profil kompetensi merupakan dokumen yang memuat daftar ranah kompetensi yang diperlukan dalam suatu pekerjaan dan sebagai perkiraan penguasaan yang tinggi kompetensi yang spesifik.

Guna lebih memahami tingkat kelengkapan. intensitas, dan tingkat kondisivitas lingkungan kelas/sekolah, secara rinci dapat dijabarkan dalam tabel-2. Dalam tabel 2, tampak bahwa faktor Guru, walaupun secara merata telah memiliki sertifikat profesi sebagai pengajar, namun teridentifikasi hanya untuk Sekolah Swasta baru mencapai 90\%. Dampaknya, secara formal masih perlu pengawasan, pendampingan dan bimbingan yang lebih intensif dari fihak terkait seperti Kepala Sekolah maupun Fihak Pengawas Sekolah.

Aspek Laboratorium khusus Mata Pelajaran Ekonomi pada sekolah swasta ternyata kurang lengkap, kurang memadai dan bahkan tidak ada. Kondisi yang memerlukan perhatian dari fihak terkait ini jika tidak terwujud memiliki dampak yang kurang mendukung upaya pemerintah dan sekolah dalam menyiapkan lulusan yang kompeten, baik untuk melanjutkan studi maupun pemilikan kompetensi kerja pada DU.DI. Namun demikian walaupun hanya mengkhususkan diri pada pembentukan 
kompetensi berwirausaha secara mandiri atau kelompok, maka fakta menunjukan bahwa dari seluruh alumnus di sekolah Negeri hanya $10 \%$ yang mampu merintis di bidang wirausaha dalam skala pemula/sangat sederhana. Sedangkan Sekoalh Swasta, tidak memilliki data tentang itu. Dalam kondisi seperti ini, jelas bahwa implikasi bagi fihak sekolah, tentunya tidak ada lain kecuali perlu mencari terobosan baru dalam upaya meningkatan pembekalan kompetensi bagi alumnusnya. Bagi sekolah yang tidak memiliki laboratorium mata pelajaran Ekonomi, tentunya dapat dilakukan dengan pembenahan strategi pembelajaran yang berorientasi pada dunia fakta di lapangan, melalui penerapan pola pembelajaran saintifik secara sungguh-sungguh dan terkontrol.

Aspek laboratorium mata pelajaran Akuntansi; dengan jenisnya berupa Lab. Khusus akuntansi, MYOB, dan Perbankan ( bukan Syariah ); untuk seluruh SMK yang diteliti memang sudah ada. Hanya Sekolah Negeri memang lebih lengkap dibanding Swasta dan demikian pula intensitasnya. Hal ini didukung oleh fakta sekolah bahwa sebagian besar siswa dan alumnus Sekolah negeri benar-benar sudah meguasai / memiliki kompetensi akuntansi dan computer akuntansi serta praktek perbankan sederhana. Namun untuk sekolah swata, data sekolah menunjukkan tingkap penguasaan akuntansi secara manual berada pada posisi rata-rata sd 70\%; kompetensi akuntansi perbankan sederhana dapat dikatakan memadai, sedangkan melalui program MYOB tidak ada. Kondisi ketidak - lengkapan sarana dan prasarana laboratorium computer akuntansi - MYOB ini sesungguhnya sangat fital bagi alumnus, Karena pada dewasa ini hamper seluru Du/Di menerapkan sitem pembukuan melalui computer dengan program sederhana seperti MYOB. Inilah sinyal yang mengindikasikan bahwa masih sangat perlunya fihak sekolah dan fihak terkait termasuk masyarakat untuk saling bersinergi dalam rangkan mewujudkan dan meningkatakan kompetensi anak bangsa.
Aspek ruang baik ruang, kelas maupun ruang perpustakaan; secara umum di Indonesia, kondisi dalam ukuran kuantitas maupun kualitasnya masih perlu terus ditingkatkan. Secara umum SMK negeri memang sudah memadai, termasuk intensitas pemanfaatannya sudah mencapai $90 \%$. Namun untuk sekolah swasta masih membutuhkan uluran tangan dan kerjasama dari berbagai fihak demi kelengkapan dan intensitas pemanfaatannya.

Aspek Kemitraan dengan Du/Di dan keluasan jaringan. Aspek ini merupakan muara dari seluruh kegiatan internal sekolah. Karena melalui penggarapan yang intens, akan membuahkan angin segar bagi alumnus maupun fihak pengajar dalam memahami dan mengevaluasi penyelenggaraan proses pembelajarannya yang menyangkut aspek materi dan kualitasnya. Di sam[ping itu tingkat keluasan mitra kerja mapun efeknya bagi perekrutan alumnus, mengindikasikan gambaran tentang kesungguhan sekolah dalam membekali dan mengantarkan alumnus ke jenjang berikutnya. Tentunya juga berdampak positif bagi calon siswa baru untuk memprioritaskan pilihannya pada sekolah yang mampu memberikan jaminan dan angin segar bagi lulusannya untuk masuk dunia kerja maupun melanjutkan ke jenjang berikutnya. Data sekolah menunjukkan bahwa sekolah Negeri masuk criteria lebih maju dalam merentang jaringan kerjanya. Terbukti telah mampu menjalin kerja sama dengan Du/Di sampai dengan Asia Tenggaramen capai 25\% alumnus 3 tahun terakhir. Namun untuk sekolah Swasta, faktanya masih sebatas lokal Karesidenan Surakarta. Hanya 10\% atau 10 orang dari lulusan SMK "C" pada 5 tahun lalu yang berhasil kerja di Perusahaan Swasta di Hongkong, itupun tidak diketahui bidang kerjanya. Keseluruhan data sekolah yang diteliti, ternyata belum memiliki data produktifitas kerja yang menyangkut aspek relevansi dan "Lama Tunggu Kerja" para alumnusnya, baik di dalam negeri maupun luar negeri. 
B. Kebijakan Internalisasi nilai-nilai soft skill dalam pembelajaran

Menanggapi fakta karakteristik kebutuhan Du/Di tersebut di atas, masing-masing sekolah dalam menginternalisasikan nilai-nilai softskills dalam pembelajaran akuntansi memiliki profil yang berbeda-beda. Perbedaan itu berdasarkan hasil wawancara dengan fihak Kepala Sekolah dan Pengajar, serta siswa, disebabkan oleh kebijakan internal yang menyangkut aspek kesiapan sekolah dan pengajar, kelengkapan sarana dan prasarana sekolah.
Internalisasi nilai-nilai soft-skills dalam pembelajaran akuntansi di atas, tampak bahwa penjelenggaraannya dilakukan melalui 2 model. 1). Model terintegrasi yaitu menyatu dengan hard skills artinya melekat dan terpadu dengan program kurikuler, kurikulum yang ada atau dalam pembelajaran yang ada atau dalam proses pembelajaran. 2). Model komplementatif, implementasi soft-skills ditambahkan ke dalam program pendidikan kurikuler dan struktur kurikulum yang ada.

Adapun cakupan dan model dimaksud tampak dalam skema beriktut:

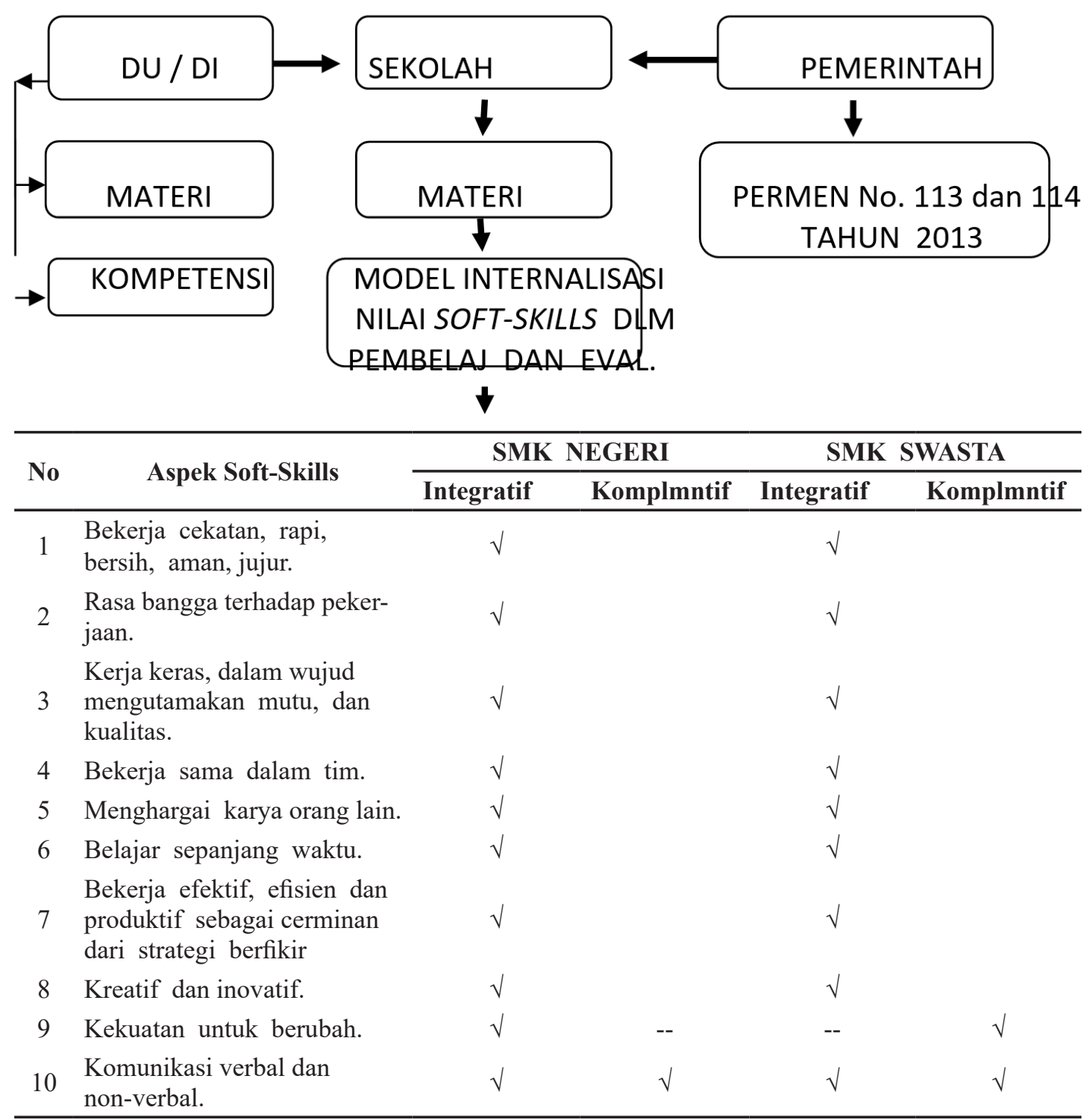

Gambar 1. Aspek soft-skills dan Model Internalisasinya dalam Pembelajaran Akuntansi 
Secara rinci, cakupan dan proses Swasta bidang ekonomi di Surakarta, tampak internalisasi nilai-nilai soft-skills dalam sebagai berikut. pembelajaran akuntansi di SMK Negeri dan

Tabel 3. Internalisasi nilai-nilai Soft-Skills dalam pembelajaran Hard-Skills di SMK-N

\begin{tabular}{|c|c|c|c|}
\hline \multirow{2}{*}{ No } & \multirow{2}{*}{ spek Soft-Skills } & \multicolumn{2}{|c|}{ SMK Negeri } \\
\hline & & Proses Pembelajaran & \multirow{3}{*}{$\begin{array}{l}\text { Bentuk/Hasil Belajar } \\
\text { Perhatian pada waktu meng- } \\
\text { amati suatu konsep dan fakta } \\
\text { tentang laporan keuangan } \\
\text { perusahaan dagang. catatan } \\
\text { yang dibuat tentang pengamat- } \\
\text { an, kesabaran, dan waktu yang } \\
\text { digunakan untuk mengamati }\end{array}$} \\
\hline 1 & $\begin{array}{l}\text { Bekerja cekatan, rapi, } \\
\text { bersih, aman, jujur. ( tam } \\
\text { pak dalam proses } 1 \text { sd } 5 \text { ) }\end{array}$ & $\begin{array}{l}\text { 1. Melihat konsep dan fakta } \\
\text { penyusunan Laporan Keuangan } \\
\text { secara kelompok. (membaca, mende- }\end{array}$ & \\
\hline 2 & $\begin{array}{l}\text { Rasa bangga terhadap } \\
\text { pekerjaan. ( proses } 1-5)\end{array}$ & $\begin{array}{l}\text { ngar, menyimak, melihat proses) } \\
\text { 2. Menanya. (membuat dan } \\
\text { mengajukan pertanyaan, tanya }\end{array}$ & \\
\hline 3 & $\begin{array}{l}\text { Kerja keras, dalam wujud } \\
\text { mengutamakan mutu, dan } \\
\text { kualitas. ( proses 1-5) }\end{array}$ & $\begin{array}{l}\text { jawab, berdiskusi tentang proses } \\
\text { penyusunan laporan keuangan yang } \\
\text { belum dipahami, informasi tambahan } \\
\text { yang ingin diketahui, atau sebagai }\end{array}$ & $\begin{array}{l}\text { Jenis, kualitas, dan jumlah per- } \\
\text { tanyaan yang diajukan peserta } \\
\text { didik ( pertanyaan faktual, }\end{array}$ \\
\hline 4 & $\begin{array}{l}\text { Bekerja sama dalam tim. } \\
\text { (dalam proses } 1-5)\end{array}$ & klarifikasi. & $\begin{array}{l}\text { kon-septual, prosedural, dan } \\
\text { hipotetik) }\end{array}$ \\
\hline 5 & $\begin{array}{l}\text { Menghargai karya orang } \\
\text { lain. ( proses } 5 \text { ) }\end{array}$ & $\begin{array}{l}\text { 3. Mengumpulkan informasi/ } \\
\text { m e n c oba. ( m e n g e k s ploras i, }\end{array}$ & jumlah dan kualitas sumber \\
\hline 6 & $\begin{array}{l}\text { Belajar sepanjang waktu. } \\
\text { ( proses } 1 \text { sd } 5 \text { ) }\end{array}$ & $\begin{array}{l}\text { berdiskusi, mendemonstra-sikan, } \\
\text { meniru bentuk/melakukan percobaan }\end{array}$ & $\begin{array}{l}\text { yang dikaji /digunakan, keleng- } \\
\text { kapan informasi, validitas infor- }\end{array}$ \\
\hline 7 & $\begin{array}{l}\text { Bekerja efektif, efisien } \\
\text { dan produktif sebagai } \\
\text { cerminan dari strategi } \\
\text { berfikir. ( proses } 1 \operatorname{sd} 5 \text { ) }\end{array}$ & $\begin{array}{l}\text { lain selain buku teks lewati angket, } \\
\text { wawancara, dokumentasi laporan } \\
\text { keuangan. }\end{array}$ & $\begin{array}{l}\text { instrument /alat yang diguna- } \\
\text { kan untuk mengumpulkan data } \\
\text { Mengembangkan interprettasi, } \\
\text { argumentasi dan kesimpulan }\end{array}$ \\
\hline 8 & $\begin{array}{l}\text { Kreatif dan inovatif. } \\
\text { ( proses } 1 \mathrm{sd} 5 \text { ) }\end{array}$ & $\begin{array}{l}\text { 4. Menalar/mengasosiasi. (mengolah } \\
\text { informasi yang sudah dikumpulkan } \\
\text { tentang laporan keuangan, } \\
\text { menganalisis data dalam bentuk } \\
\text { menghubungkan informasi yang } \\
\text { terkait dalam rangka menemukan }\end{array}$ & $\begin{array}{l}\text { mengenai keterkaitan informasi } \\
\text { dari dua fakta/ konsep, } \\
\text { interpretasi argumentasi dan } \\
\text { kesimpulan tentang laporan } \\
\text { keuangan perusahaan dagang. }\end{array}$ \\
\hline 9 & $\begin{array}{l}\text { Kekuatan untuk berubah } \\
\text { lebih maju. ( proses } 1-5)\end{array}$ & $\begin{array}{l}\text { suatu pola, dan menyimpulkan } \\
\text { fakta/ konsep/teori, menyintesis } \\
\text { dan argumenttasi tentang laporan }\end{array}$ & $\begin{array}{l}\text { Menyajikan hasil kajian (dari } \\
\text { mengamati sampai menalar } \\
\text { dalam bentuk laporan keu- }\end{array}$ \\
\hline 10 & & & $\begin{array}{l}\text { angan perusahaan dagang } \\
\text { secara tetulis. Untuk selanjutnya }\end{array}$ \\
\hline & & $\begin{array}{l}\text { 5. Mengkomunikasikan / presentasi } \\
\text { hasil. (menyajikan lapor-an yang } \\
\text { meliputi proses, hasil, dan kesimpulan } \\
\text { secara tertulis ) }\end{array}$ & $\begin{array}{l}\text { dipresentasikan dalam diskusi } \\
\text { kelompok. }\end{array}$ \\
\hline
\end{tabular}

Hasil kajian sebagaimana tabel di atas, juga senada dengan pendapat Bergh, et all (2006) yang meneliti tentang pengembangan soft-skills melalui guiding dan growing menjelaskan bahwa integrasi soft skills kedalam kurikulum memberi variasi pengalaman pembelajaran terutama saat berinteraksi dengan pasien. Melalui kegiatan pembelajaran yang diciptakan dosen membantu mengembangkan dan menkonstruk soft skills secara mandiri. Nealy (2005) meneliti tentang integrasi soft skills melalui pembelajaran aktif menemukan bahwa pembelajaran aktif telah menumbuhkan soft skills dan skills lainnya yang diperlukan untuk meningkatkan performa kerja di era abad 21 ini. 
Tabel 4. Internalisasi nilai-nilai Soft-Skills dalam pembelajaran Akuntansi di SMK-Swasta

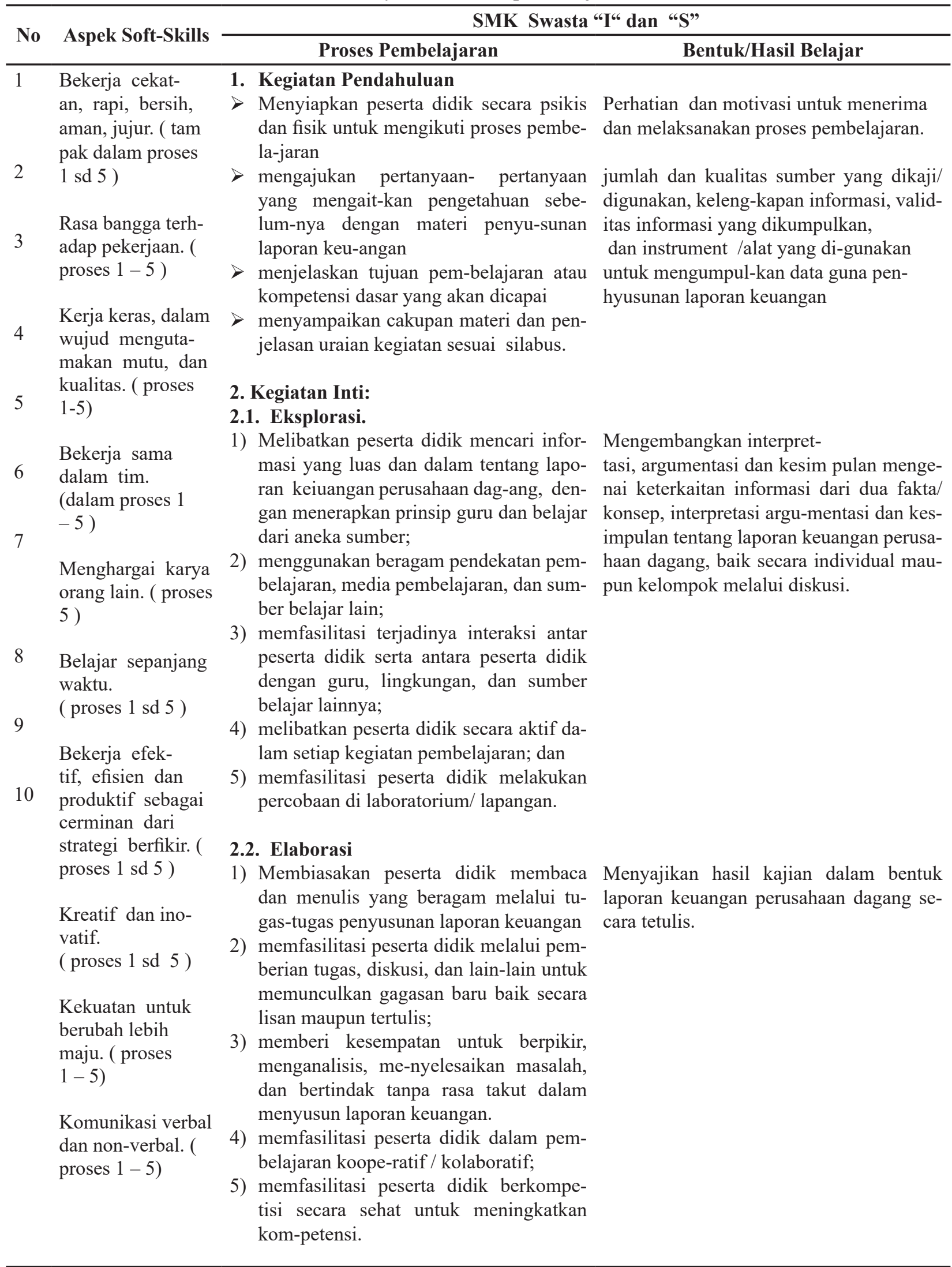




\begin{tabular}{|c|c|c|}
\hline \multirow{2}{*}{ No } & \multirow{2}{*}{ Aspek Soft-Skills } & SMK Swasta \\
\hline & & Proses Pembelajaran \\
\hline & & $\begin{array}{l}\text { 6) Memfasilitasi peserta didik dalam peny- } \\
\text { usunan laporan keuangan perusahaan da- } \\
\text { gang }\end{array}$ \\
\hline & & $\begin{array}{l}\text { 7) memfasilitasi peserta didik untuk men- } \\
\text { yajikan kreasi; kerja individual maupun } \\
\text { kelompok; }\end{array}$ \\
\hline & & $\begin{array}{l}\text { 8) memfasilitasi peserta didik melakukan ke- } \\
\text { giatan yang menumbuhkan kebanggaan } \\
\text { dan rasa percaya diri peserta didik. }\end{array}$ \\
\hline
\end{tabular}

\subsection{Konfirmasi}

1) Bersama-sama dengan peserta didik dan/atau sen-diri membuat rangkuman / simpulan pelajaran;

2) melakukan penilaian dan / atau refleksi terha-dap kegiatan yang sudah dilaksanakan secara konsisten dan terprogram;

3) memberikan umpan balik terhadap proses dan hasil pembelajaran;

4) merencanakan kegiatan tin-dak lanjut dalam bentuk pembelajaran remidi, dan/ atau memberikan tugas balk tugas individual maupun kelompok.

5) menyampaikan rencana pe-mbelajaran pada perte-muan berikutnya.
Membuat kesimpulan yang benar secara mandiri/ kelompok dengan fasilitasi pengajar.

Menyelesaikan tugas di kelas maupun melakukan pengembangan di lapangan. Menyiapkan diri untuk mengawali kajjian terhadap materi berikutnya di perpustakaan atau dirumah.

\section{Kegiatan Akhir.}

- Refleksi oleh guru

Refleksi bersama pengajar.

Bertolak dari paparan di atas, dapat ditegaskan bahwa penggunaan kurikulum oleh sekolah negeri dan swasta memang masih belum seragam. SMK Negeri sudah menggunakan Kurikulum 2013, sedangkan SMK Swasta tetap menggunakan kurikulum KTSP, walaupun pelaksanaan Kurikulum 2013 dilakukan secara bertahap dan berjenjang.

Konsekuensi dari penerapan kurikulum tersebut berdampak pada penyelenggaran system evaluasi pembelajarannya. Khusus pada SMK Negeri menggunakan model Authentik dengan pendekatan Rubrik. Namun demikian pada penyelenggaraan KTSP di Sekolah Swasta berdasarkan hasil wawancara, observasi dan fakta dokumentasi proses, mode konvensional, tetapi untuk penilaian siwa kelas 7 , sudah menggunakan pendekatan model Authentik, yang mengukur dan menilai seluruh aspek kompetensi secara wutuh meliputi aspek kompetensi pengetahuan, sikap dan ketrampilan.

\section{Simpulan}

Berdasarkan kajian hasil penggambaran internalisasi nilai-nilai soft- skills dalam pemebelajaran akuntansi maka dapat disimpulkan sebagai berikut: 1). SMK di Serakarta telah secara wutuh mengadopsi Jenis soft-skills yang diterapkan DU/Di, perbedaan aplkasinya terletak pada aspek intensitasnya, di mana SMK Negeri lebih intensif disbanding SMK Swasta. 2). Internalisasi nilai-nilai soft- skills dalam pembelajaran akuntansi yang diselenggarakan di kedua kelompok SMK tersebut cenderung tidak berbeda, SMK Negeri mengguakan pendekatan "Integratif", sedangkan SMK Swasta menggunakan pendekatan "Komplementatif dan integratif". 
3). Model evaluasi yang diadopsi SMK dan berjenjang mengadopsi pendekatan Negeri menggunakan pendekatan Authentik, Konvensional untuk selanjutnya diterapkan sedangkan SMK Swasta secara bertahap pendelatan Authentik.

\section{Daftar Pustaka}

Amirulloh. 2015. Teori Pendidikan Karakter Remaja dalam Keluarga. Bandung: Alfabeta.

Baedhowi. 2008. Kebijakan pengembangan pendidikan guru kejuruan. Makalah Seminar Internasional. Optimalisasi Pendidikan Kejuruan dalam Pengembangan SDM Nasional Dalam Rangka Konvensi Nasional APTEKONDO V. FT. UNP, Padang 4 Juni 2008.

Depdikbud, 1989. Materi Pelatihan Pembelajaran Akuntanasi. Jakarta: P2A.

Elliot, Janet. 2003 The Organization of Productive Work In Secondary Technical and Vocational Education The United Kingdom. London: Unesco.

Finch,R.C \& Crunkilton, R.J. 1989. Curriculum development in vocational and technical education. Massachusetts: Allyn and bacon, Inc.

Gandhi. 2002. Akuntansi Keuangan. Jakarta: Aksara.

Herminarto Sofyan. 2008. Pengembangan soft skills dan pembelajarannya. Makalah disajikan dalam Seminar Mencetak Guru Profesional dan Kreatif Bidang Vokasi, di Jurusan PTBB Fakultas Teknik Universitas Negeri Yogyakarta.

Moleong, L. 1991. Metodologi penelitian kualitatf Bandung: PT Remaja Rosdakarya.

Mudakhir Ilyas. (1998), Buletin pengawasan No. 13 \& 14 Th. 1998.

Muchlas Samani. 1992. Keefektifan Program Pendidikan STM: Studi Penelitian Pelacakan terhadap Lulusan STM Rumpun Mesin Tenaga dan Teknologi Pengerjaan Logam di Kotamadya Surabaya tahun 1986 dan 1987. Disertasi doktor IKIP Jakarta.

Nealy,C. 2005. Integrating soft skills Through active learning in the management classroom. Journal of Collage teaching \& learning. Vol 2 number 4. April 2005.

Neff and Citrin. 1999. Percentage of Soft Skill as Success Component.

Sugiyono. 2006. Metode penelitian pendidikan. Bandung: Alfabeta.

Sutomo dan Budi Sutrisno 2013. Manajemen dan organisasi sekolah kejuruan Dalam pembentukan sekolah Berwawasan global. Jurnal PIPS - Vol.22, No. 1. Juni 2012.

Sutopo, N.B. 2006. Metodologi Penelitian Kualitatif. Surakarta: Universitas Sebelas Maret.

Sutrisno, Budi. 2013. Perencanaan Karir Siswa ( Sebuah Model berbsis Pengembangan SoftSkills). Jurnal Varia Pendidikan ISSN, No.0852-0976. Vol. 25 No, 1 Juni 2013: 1 - 14

Widarto, pardjono, dan Widodo. TT. Pengembangan Model Pembelajaran Soft Skills dan hard Skill. Yogyakarta: Universitas Negeri Yogyakarta 